\title{
Late Cenozoic tectonic evolution of the Transylvanian basin and northeastern part of the Pannonian basin (Romania): Constraints from seismic profiling and numerical modelling
}

\author{
D. Ciulavu ${ }^{1}{ }^{*}$, C. Dinu ${ }^{1}$, and S. A. P. L. Cloetingh ${ }^{2}$ \\ ${ }^{1}$ Bucharest University, Faculty of Geology and Geophysics, 6 Traian Vuia st, 70139 Bucharest, Romania \\ *Present address: Shell Canada Ltd, 400-4th Ave S.W., P.O. Box 100, Station M, Calgary, Alberta T2P 2H5, Canada \\ ${ }^{2}$ Vrije Universiteit, Department of Sedimentary Geology, Institute of Earth Sciences, De Boelelaan 1085, 1081 HV \\ Amsterdam, The Netherlands
}

Received: 22 December 2000 - Accepted: 16 July 2001

\begin{abstract}
The Transylvanian and the Pannonian basins are presented as basins with different tectonic evolution. In this paper, seismic lines are used to highlight the late Cenozoic structural pattern of the Transylvanian Basin and of the northeastern sector of the Pannonian Basin. Late Miocene transpressional strike-slip faults have been interpreted in both areas. North- to northeast-oriented regional stress field has been inferred from the structures interpreted in both areas. The similar structural pattern and stress field indicate a common late Cenozoic tectonic evolution of these two areas. A finite element model has also been carried out in order to investigate which orientation of late Cenozoic far-field stress are most likely to be responsible for the complex structural pattern of these two areas. The finite element modeling also indicates that the complex late Cenozoic structural pattern observed within the studied areas, but also around them, is most likely the result of a coherent northeast-oriented farfield compressional stress.

Our results indicate a Pliocene intraplate stress field similar to the one documented by Horvath and Cloetingh, (1996) in the Pannonian Basin.
\end{abstract}

\section{Introduction}

The Transylvanian and the Pannonian basins are located in the eastern sector of the European Alpine chain (Fig. 1). The Apuseni Mountains and few isolated mountains related to them represents the boundary between the Transylvanian and the Pannonian basins. These two basins display different geological and geophysical characteristics: (1) the heatflow of the Pannonian Basin is about of $100-120 \mathrm{~mW} / \mathrm{sqm}$, while the heat-flow of the Transylvanian Basin is about 40-

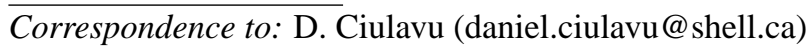

$50 \mathrm{~mW} / \mathrm{sqm}$ (e.g. Demetrescu and Veliciu, 1991), (2) the average elevation of the Transylvanian Basin above sea level is relatively high, around $600 \mathrm{~m}$; the difference in elevation of the Upper Miocene deposits from the Transylvanian and the Pannonian basins is more than $1000 \mathrm{~m}$ (Ciupagea et al., 1970). Moreover, a Miocene extensional origin of the Pannonian Basin is documented, while a Miocene retroforeland setting (e.g. Sanders, 1998) or a Miocene compressional/transpressional setting have been suggested for the Transylvanian Basin (e.g. Ciulavu et al., 2000).

Since the Pliocene, an overall compressional/transpressional stress regime is interpreted in the Pannonian Basin (Horvath and Cloetingh, 1996), and in the Transylvanian Basin (Ciulavu et al., 2000). Both basins are characterised by low to medium level of crustal seismic activity (Horvath and Cloetingh, 1996; Ciulavu et al., 2000). The average magnitude (M) of the earthquakes is about 4, with a maximum magnitude up to 6 recorded only in the central part of the Pannonian Basin (Horvath and Cloetingh, 1996).

In the studied area, the boundary between the Transylvanian and Pannonian basins is the narrowest, being represented only by few isolated metamorphic basement blocks (Fig. 1). This closest position of the two basins makes the comparison between them easier and more reliable. Until now, structural and seismic data from the Transylvanian Basin have been published (De Broucker, 1998; Ciulavu, 1999; Ciulavu et al., 2000) but not from the northeastern sector of the Pannonian Basin. Two seismic lines from the Transylvanian Basin, acquired by former Shell Romania exploration $\mathrm{BV}$, and four seismic lines from the northeastern part of the Pannonian Basin, acquired by Prospectiuni SA are presented and compared in this paper. Geological boundaries have been interpreted using borehole data. Published 


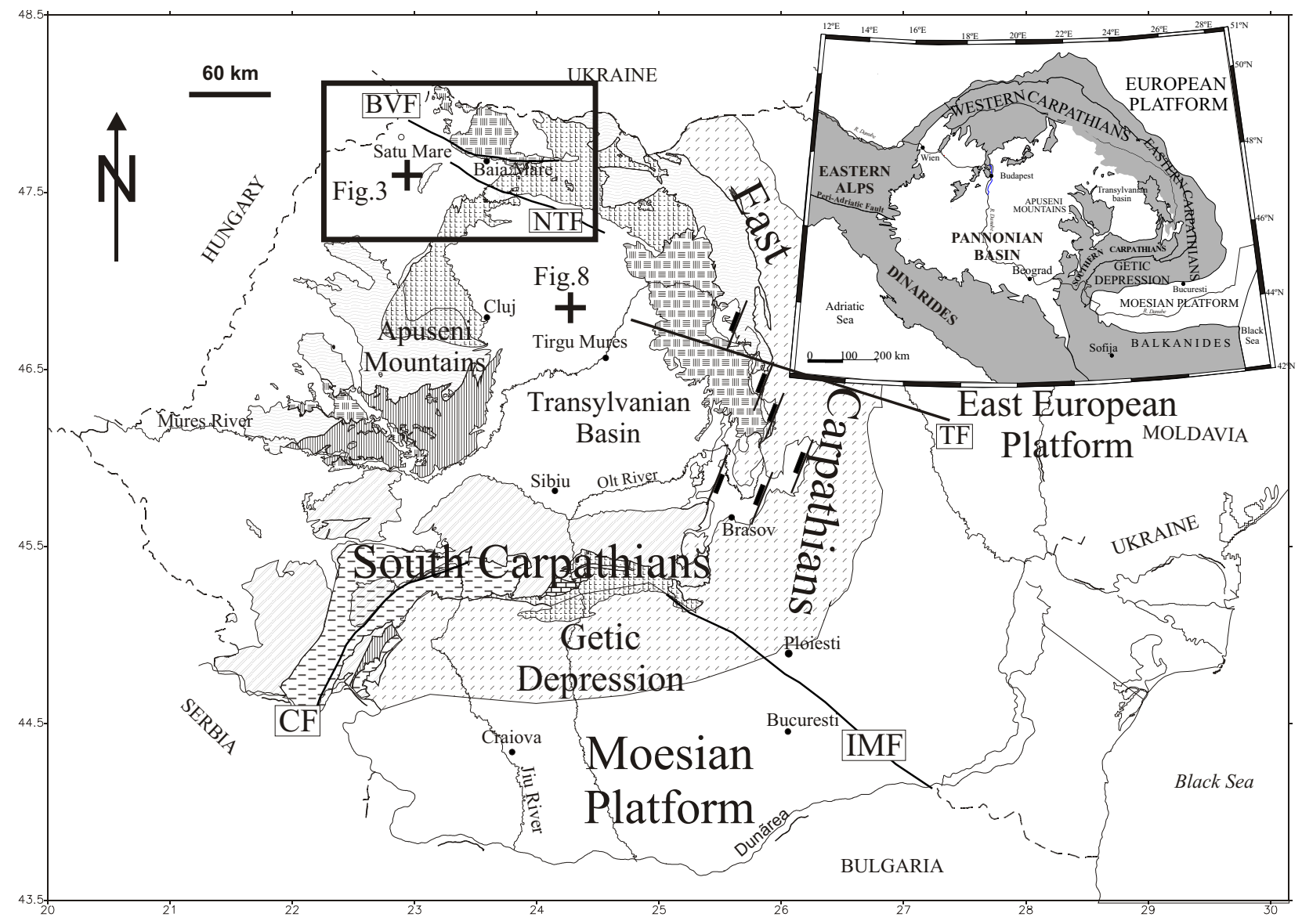

\begin{tabular}{|c|c|c|c|}
\hline \multirow{5}{*}{ Legend } & East Carpathians & Apuseni Mountains & Southern Carpathians \\
\hline & Metamorphics & $\begin{array}{l}\text { Northern Apuseni } \\
\text { Mountains }\end{array}$ & $\begin{array}{l}\text { Getic and } \\
\text { Supragetic } \\
\text { nappes }\end{array}$ \\
\hline & Post-tectonic cover & $\begin{array}{c}\text { Southern Apuseni } \\
\text { Mountains }\end{array}$ & nappes \\
\hline & \multirow{2}{*}{$\begin{array}{l}\text { Flysch Nappes } \\
\text { and folded } \\
\text { sedimentary strata }\end{array}$} & Mountains & Severin Nappe \\
\hline & & & Danubian realm \\
\hline & cs & posits & $\begin{array}{l}\text { Pol } \\
\text { bou }\end{array}$ \\
\hline
\end{tabular}

Fig. 1. Geologic sketch of Romania. Location of study area is highlighted by the black rectangle. Symbols represent CF - Cerna Fault, IMF - Intra-Moesian Fault, TF - Trotus Fault, NTF - North Transylvanian Fault and BVF - Bogdan Voda Fault. The inset represents the geologic sketch of the Carpathian-Pannonian area.

paleostress data are also incorporated. The late Cenozoic structural pattern of both areas is characterised by transpressional strike-slip faults indicating a common tectonic evolution for this time span. A finite element model has also been carried out in order to investigate which orientation of late Cenozoic far-field stress are most likely to be responsible for the complex structural pattern of these two areas. A coherent northeast-oriented far-field compressional field is most likely responsible for the structural pattern in both areas.

\section{Regional geological setting}

The arcuate Carpathian thrust-and-fold belt represents the result of the Cretaceous to Miocene subduction and collision between European plate and several smaller continental blocks to the south (e.g. Sandulescu, 1984). Southward, the 
Carpathians connect to the north-directed Bulgarian Balkan chain along a north-trending dextral wrench system (Fig. 1), to which Cerna Fault belongs. To the west, the Carpathians are linked to the eastern Alps. The eastern Alps are separated from the Southern-Dinaric Alps by the peri-Adriatic line.

The main area of paleo-oceanic units in Romanian Carpathian is the Vardar-Mures unit, which derives from a former oceanic lithosphere that formed during Mid Triassic and Mid-Jurassic rifting phases (e.g. Sandulescu, 1984). The rocks of the Vardar-Mures unit cropout in the Southern Apuseni Mountains and are interpreted to extend beneath the eastern part of the Transylvanian Basin (e.g. Sandulescu, 1984; Fig. 1).

West and east of the Mures unit, in the Northern Apuseni Mountains, East and South Carpathians, a system of basement and cover nappes was developed during the Cretaceous (Bleahu, 1976; Sandulescu, 1984; Fig. 1).

After the Paleogene, thin-skinned deformation is documented in the external part of the Carpathians, where about $180 \mathrm{~km}$ of shortening took place (e.g. Roure et al., 1993; Matenco, 1997). Late Burdigalian thin-skinned deformation is also documented in the internal part of the Carpathians, in the Pienides (Sandulescu, 1988). The Miocene thin-skinned deformation from the external part progressively migrated eastward, along the Carpathian chain (e.g. Sandulescu, 1988). The Miocene extension documented in the Pannonian Basin is coeval with an important stage of nappe emplacement in the East Carpathians (e.g. Royden, 1993), and with transpressional strike-slip deformation in the Transylvanian Basin (Ciulavu et al., 2000). Magmatic activity followed, or was coeval, to the Miocene cover nappe emplacement. Neogene calk-alkaline magmatism (K-Ar dating indicates $13.4 \mathrm{Ma}-$ $0.2 \mathrm{Ma}$ and a decrease of the age of volcanism from north to south) occurs along the northern and eastern borders of the Transylvanian Basin (Lang et al., 1994; Pecskay et al., 1995). Neogene (15 Ma-7 Ma) calk-alkaline magmatism, without any coherent geodynamical explanation so far, occurs in the Apuseni Mountains (e.g. Borcos, 1994; Rosu et al., 1997).

In the Carpathian-Pannonian area, blocks finally locked into their positions in late Miocene. Surface and subsurface data indicate a coherent late Miocene to Pliocene north- to northeast-oriented compression in the Carpathians, foreland and foredeep of the Carpathians, west of the Intra Moesian Fault, and in the Transylvanian Basin and its rims (Bergerat, 1987; Ratschbacher et al., 1994; Hippolyte and Sandulescu, 1997; Matenco, 1997; Ciulavu et al., 2000). A Pliocene overall compressional tectonic regime is documented in the Pannonian Basin (Horvath and Cloetingh, 1996). At a regional scale, the present day maximum horizontal stress, inferred from earthquake focal mechanism solutions, borehole breakouts and in-situ stress measurements, is northwest-oriented (in the northern area), north- to northeast-oriented (in the central area), and west-east-oriented (in the eastern area) (Bada et al., 1998). This stress induced large-scale bending or folding of the litosphere and fairly explains the observed Quaternary differential uplift and subsidence pattern (Hor- vath and Cloetingh, 1996). At the crustal scale, this stress is reflected in transpressive structures in both areas (Tari, 1994; Ciulavu et al., 2000). The importance of these faults is pointed out by the fact that movement along them are responsible for the uplift of the isolated mountains which cropout in the Pannonian Basin (Tari, 1994; Fig. 1).

Strike-slip deformation is responsible for a succession of subsidence and uplifted areas from the Pannonian Basin, from the southeastern sector of the Transylvanian Basin and from a zone of the Carpathians and their foreland, bordered by the seismically active intra-Moesian and Trotus faults (Horvath, 1993; Ciulavu et al., 2000). In the foreland area, between the Trotus and the Intra Moesian faults, intermediate foci occur in a rather small, quasi-vertical area down to about $200 \mathrm{~km}$. These earthquakes are interpreted as a result of stress-concentration at the bent of the Carpathians (Roman, 1970).

\section{Geological setting of the studied areas}

To highlight the geological setting of the studied areas, chrono-stratigraphic charts of the Transylvanian Basin, after Ciulavu et al. (2000), and of the northeastern part of the Pannonian Basin, after Bleahu et al. (1967) are presented (Fig. 2). Ages are given in million of years after Rög (1996). It should be mentioned that, in the studied areas, the Lower Sarmatian is used as Sarmatian sensu stricto (Sarmatian s. str.) and the Upper Sarmatian and the Maeotian as the Pannonian sensu stricto, referred below as Pannonian (e.g. Nicorici and Meszaros, 1994).

The basement of the Transylvanian and Pannonian basins is made up of a nappe pile consisting of metamorphic rocks and associated sedimentary strata, similar to what is currently exposed in the surrounding mountains; ophiolitic rocks of the Vardar-Mures zone are subcropping in the basement of the Transylvanian Basin (Fig. 2).

Upper Cretaceous shallow-water sedimentary deposits are documented in the Transylvanian Basin. These deposits are missing in the studied area of the Pannonian Basin but are subcropping southward, in the same facies as in the Transylvanian Basin (Visarion et al., 1979). An Eocene continentalmarine succession of sedimentary sequences, deposited in an overall compressional setting, is developed in the Transylvanian Basin. The Eocene compressional setting led to uplift of the northeastern part of the Pannonian Basin and probably to non-deposition. Oligocene deep-water deposits are known in both studied areas. Structural work carried out in the Transylvanian Basin indicates Oligocene north-oriented tension, followed by northwest-oriented compression (Huismans et al., 1997).

During the Burdigalian, no sediments have been deposited in the northeastern part of the Pannonian Basin (Sandulescu, 1984). A Burdigalian sedimentary wedge, thinning southward, is developed in the Transylvanian Basin. This geometry was interpreted to indicate a (retro-)foreland basin (Huismans et al., 1997; Sanders, 1998; De Broucker et al., 1998; 


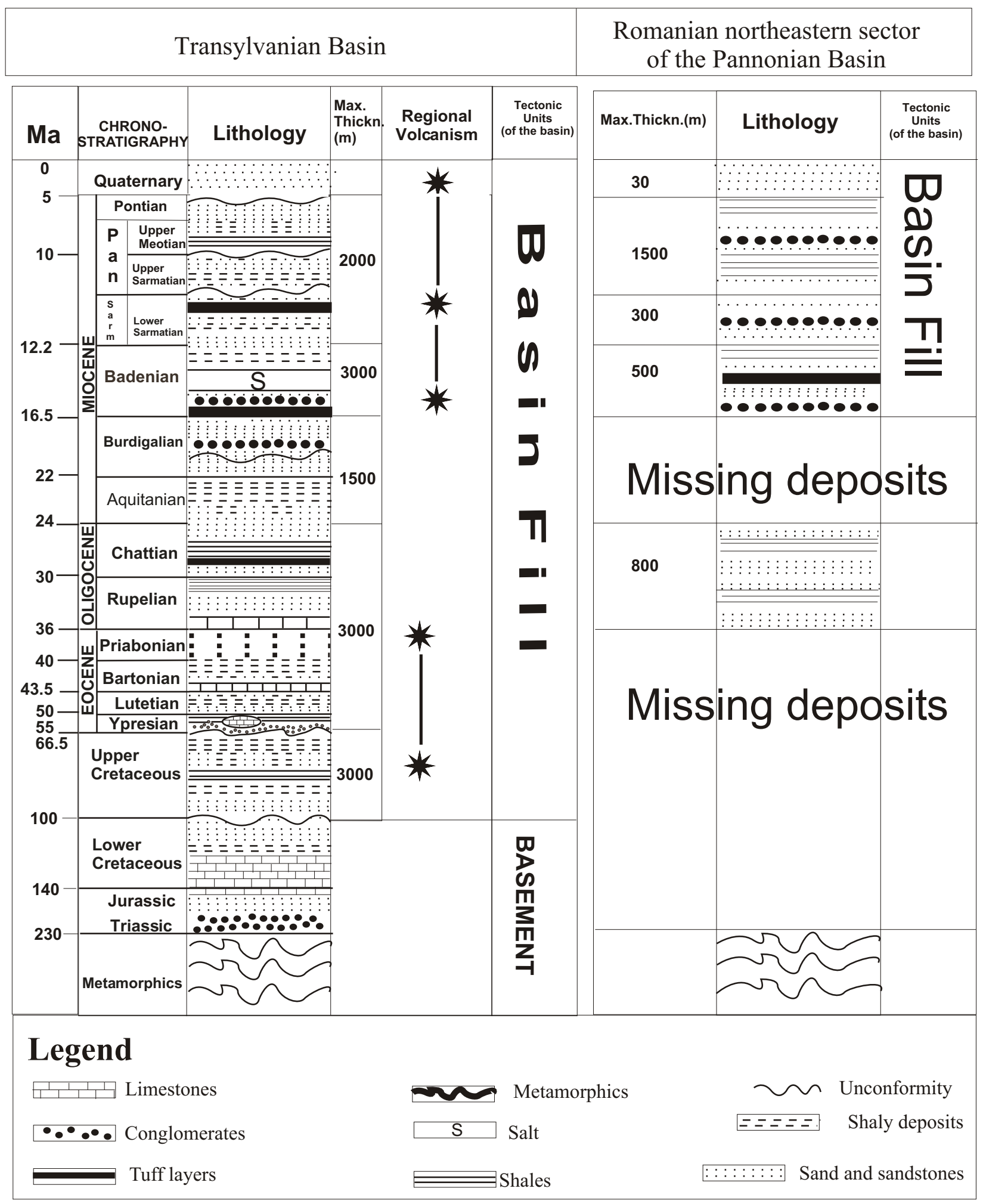

Fig. 2. Stratigraphycal columns of the Transylvanian Basin and of the Romanian northern sector of the Pannonian Basin. Simplified after Bleahu et al. (1967) and Ciulavu et al. (2000).

Ciulavu et al., 2000). Structural work performed in this area indicates Early Miocene north-northeast-oriented compression (Huismans et al., 1997).
Starting from Badenian the sedimentation is continuous in the northeastern part of the Pannonian Basin while a few gaps are documented in the Transylvanian Basin (e.g. 


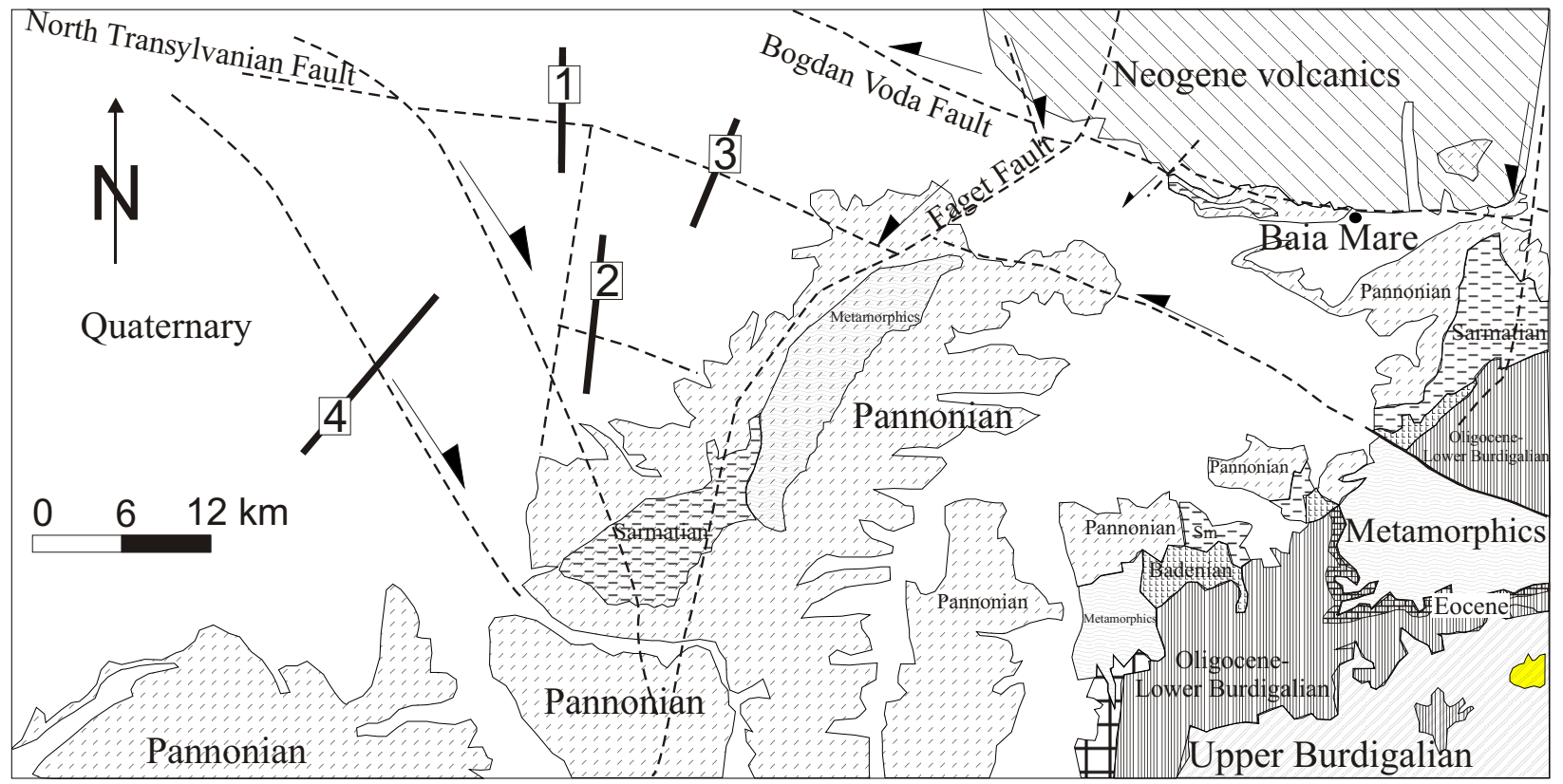

\section{Legend}
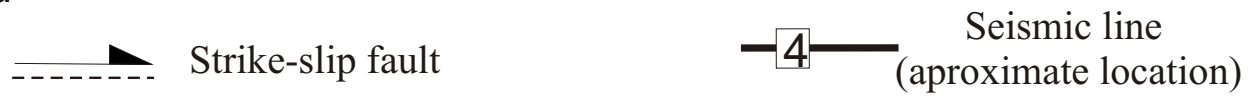

Fig. 3. Geological sketch of the Romanian northern sector of the Pannonian Basin (simplified after Bleahu et al., 1967). See Fig. 1 for location. The faults and sense of movement are drawn after Sandulescu et al. (1993) and Visarion et al. (1979).

De Broucker et al., 1998). Badenian sedimentary deposits are different in the two studied areas, e.g. salt formation is known in the Transylvanian Basin but not in the Pannonian Basin. Structural work carried out in the Transylvanian Basin indicates late Miocene east-west-oriented tension followed by compression with the same orientation (Huismans et al., 1997). Starting from late Miocene, an uplift of the northern sector of the Transylvanian Basin and of the northeastern sector of the Pannonian Basin is interpreted because the late Badenian and younger sediments onlap the older ones in both areas (e.g. Ciupagea et al., 1970; De Broucker et al., 1998). This uplift is also confirmed by fission-track analysis (Sanders, 1998).

\section{Northeastern sector of the Pannonian Basin}

The North Transylvanian and Bogdan Voda faults are interpreted to control the tectonic evolution of this area (Fig. 3). Areas of uplift and subsidence are documented between these two faults (Sandulescu et al., 1993). The North Transylvanian and Bogdan Voda faults are west-trending sinistral strike-slip faults. The main movement along the North Transylvanian Fault took place during the intra-Burdigalian time, while along the Bogdan Voda Fault the main movement took place at the Burdigalian-Badenian boundary (e.g. Sandulescu et al., 1993). Earthquakes with Richter magnitude (M) up to 4.9 and focal depth up to $15 \mathrm{~km}$ are recorded along them (Cornea and Lazarescu, 1980).

The North Transylvanian and Bogdan Voda faults are crosscut by northwest-striking dextral and northeast-striking sinistral strike-slip faults (Fig. 3). The Faget and Mara faults are the most important northeast-striking sinistral strike-slip faults. The Faget Fault is interpreted as representing the western boundary of the Pienides (e.g. Sandulescu et al., 1993). The Faget Fault played an important role in the geological evolution of the area because it also represents the western boundary of the uplifted basement blocks and the boundary of areas with different Miocene sedimentation (e.g. Sandulescu et al., 1993). The Halmeu Fault is the most important northwest-trending dextral strike-slip fault; it is formed in a transpressional tectonic regime (e.g. Sandulescu et al., 1993).

In this area, the boundary between the Transylvanian and Pannonian basins is represented by uplifted blocks of metamorphic basement, which surround areas of subsidence (Fig. 3). The last uplift of the basement took place during the Pliocene (e.g. Ciupagea et al., 1970). 


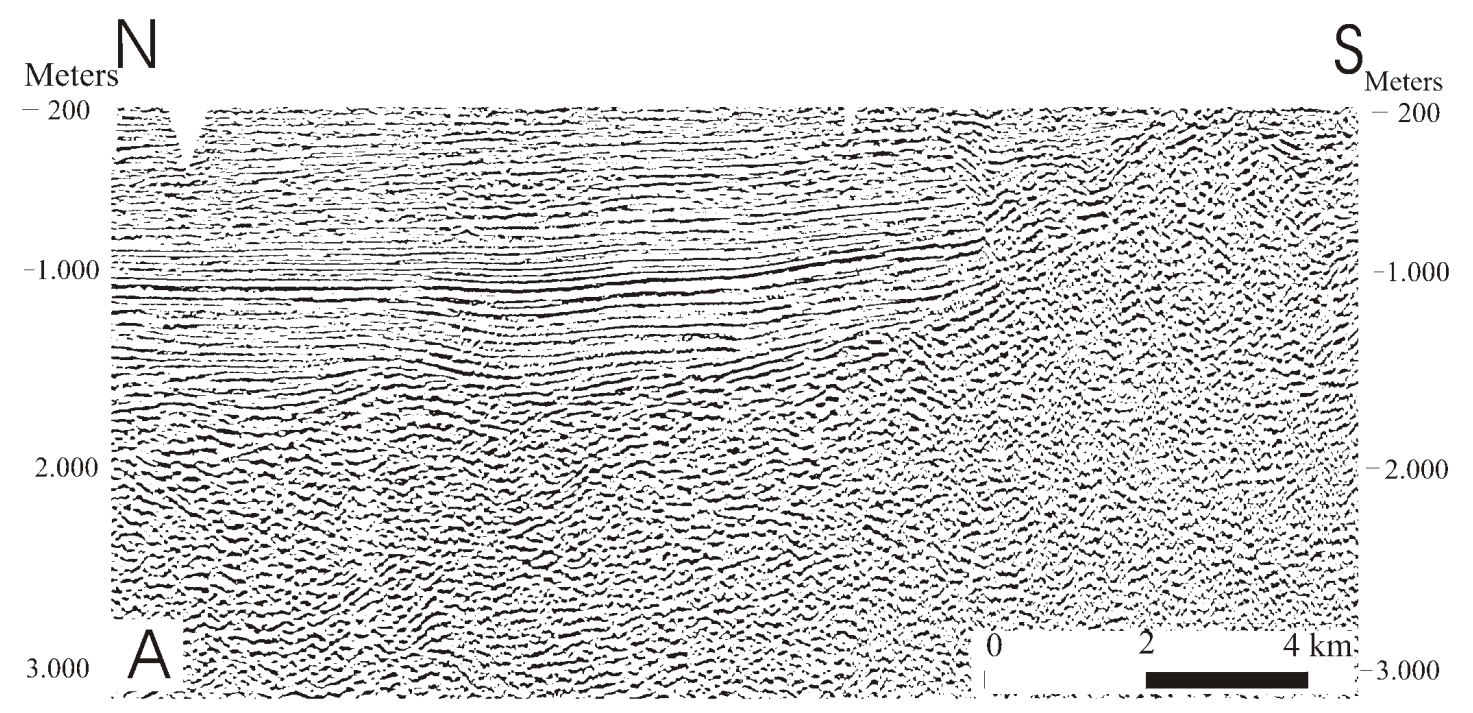

\section{Line 1}

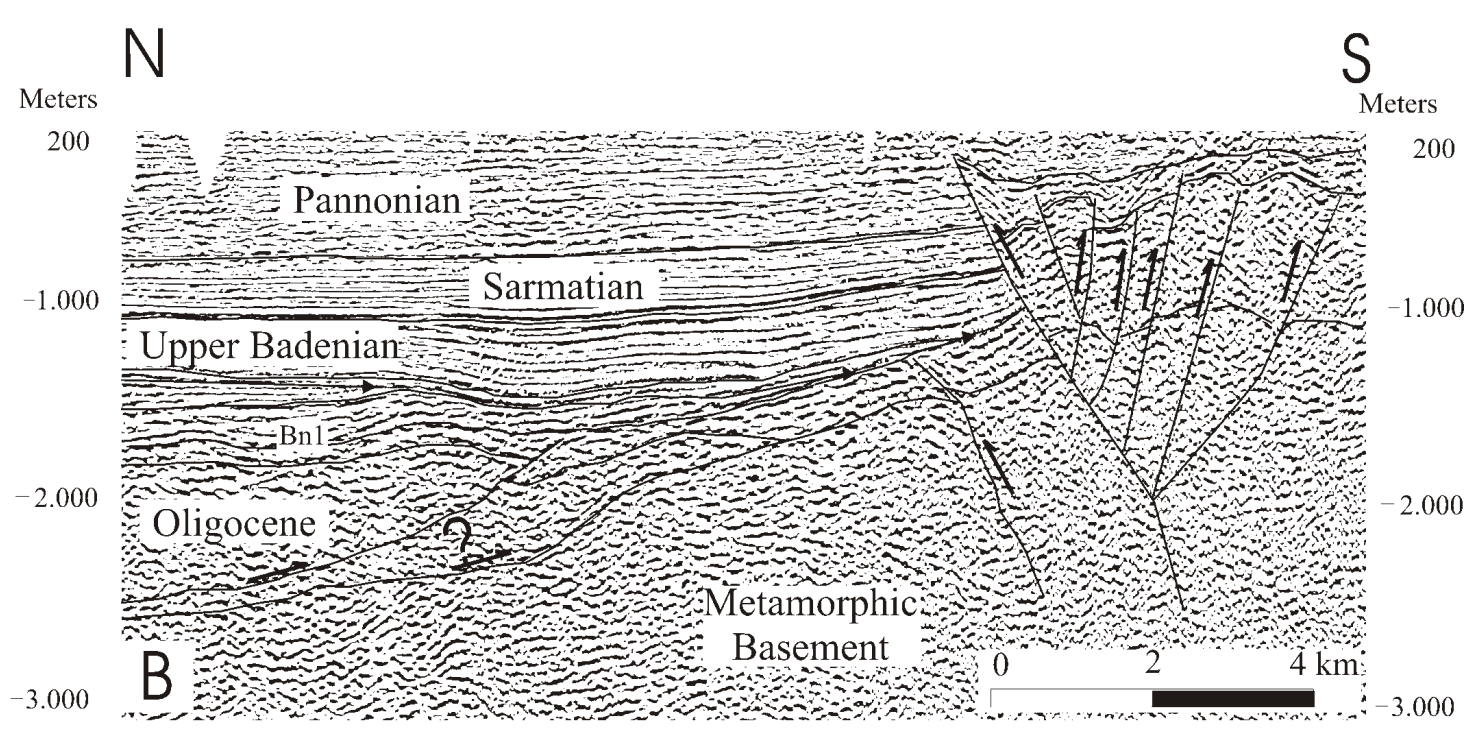

Fig. 4. (A) Line 1 shot above the North Transylvanian Fault (see Fig. 3 for location). (B) Interpretation. Symbol Bn1 represents Lower Badenian. Oligocene deposits overlying metamorphic basement are interpreted in the northern part of the line between $-3000 \mathrm{~m}$ and $1500 \mathrm{~m}$. In the same part of the line the Upper Badenian sediments onlap the folded Lower Badenian and the Oligocene ones. The North Transylvanian Fault is visible in the southern part of the line, and is made of upward diverging splays with reverse component, characteristics of positive flower structure (Harding, 1990). The metamorphic basement and the whole sedimentary sequence are involved in deformation. The offset is about of $400 \mathrm{~m}$.

\section{Seismic lines from the northeastern sector of the Pan- nonian Basin}

Strike-slip movement in a transpressional regime is interpreted along the North Transylvanian Fault. Basement blocks as well as late Cenozoic sedimentary deposits are involved in deformation. A positive flower structure (Harding, 1990) is imaged in the line 1 (Fig. 4, see Fig. 3 for location). The age of the structure is post-Miocene since the Pannon- ian deposits are involved in deformation. Faulted and folded Oligocene and Lower Badenian deposits are imaged in the southern part of the line. The Upper Badenian deposits onlap the older one, similar with the structure of piggy-back basins. Another positive flower structure is imaged in line 2 (Fig. 5, see Fig. 3 for location). The age of the structure is post-Miocene since the Pannonian deposits are involved in deformation. Two north-dipping thrust faults crosscutting 

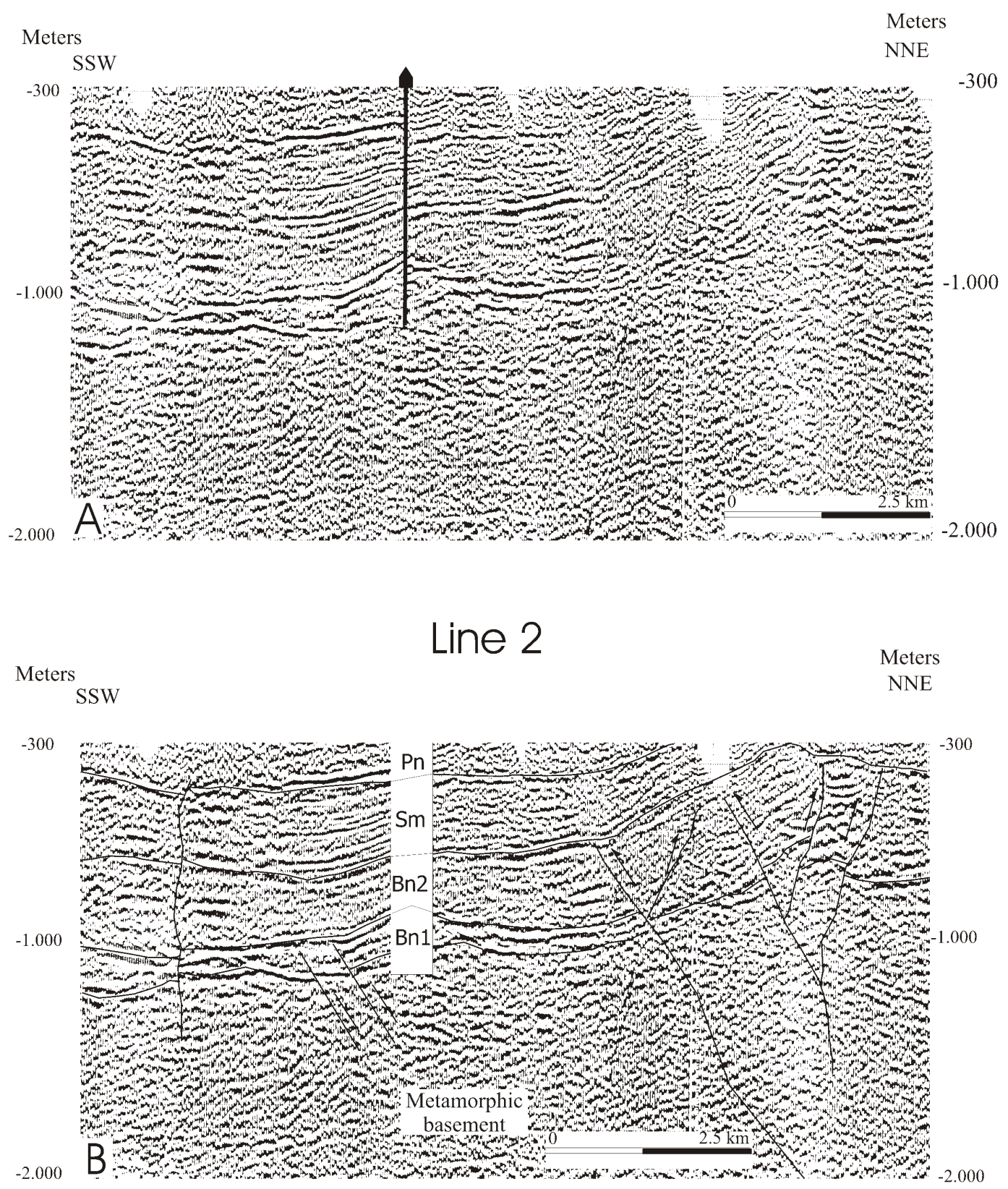

Fig. 5. (A) Seismic line 2, shot above a fault south and parallel to the North Transylvanian Fault (see Fig. 3 for location). (B) Interpretation. Symbols represent Bn1 - Lower Badenian, Bn2 - Upper Badenian, Sm - Sarmatian, Pn - Pannonian. Two positive flower structures are interpreted in the northern part of the line. The metamorphic basement and the whole sedimentary sequence are involved in deformation. The total uplift of the block affected by the flower structures is about of $400 \mathrm{~m}$. Two reverse faults crosscutting the Lower Badenian deposits are interpreted in the central part of the line. A vertical fault crosscutting the base of the Pannonian deposits is interpreted in the southern part of the line.

the Lower Badenian deposits are imaged in the central part of the line. A vertical fault crosscutting the whole lithological sequence is interpreted in the southern part of the line.

The North Transylvanian Fault is imaged as a high-angle, south-dipping reverse fault in line 3 (Fig. 6, see Fig. 3 for location). The fault crosscuts the whole lithological sequence. Therefore, a post-Miocene age is also interpreted for the North Transylvanian Fault in this sector.

Upward diverging splays characteristics for flower struc- tures are interpreted in the central part of line 4 (Fig. 7, see Fig. 3 for location). The sense of movement for each splay is not clear because of intense deformation. Nevertheless, we interpret this structure as a positive flower because of the existence of two splays with reverse movement, which crosscut the Badenian sequence. The whole sedimentary sequence is folded. A post-Miocene age of the positive flower structure is assumed since it also crosscuts the Pannonian deposits. 


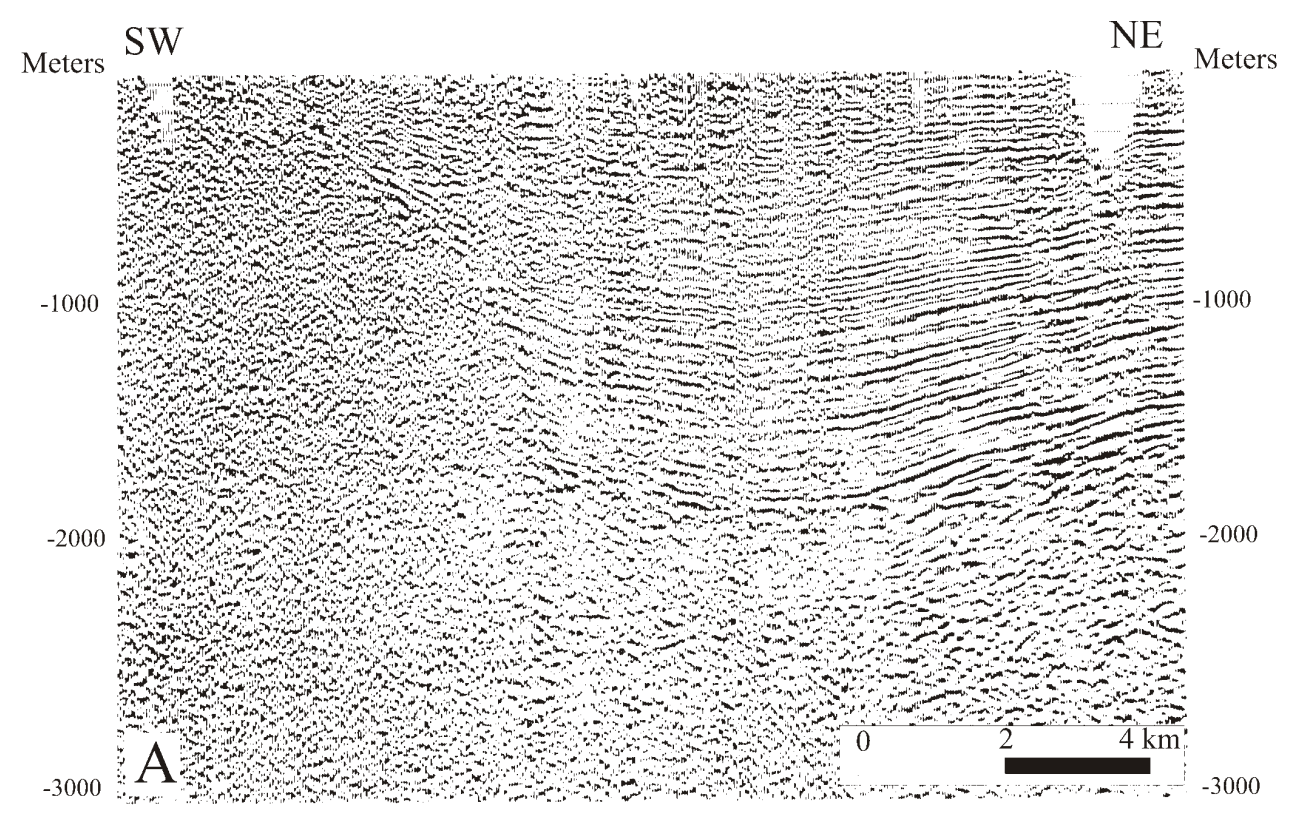

\section{Line 3}

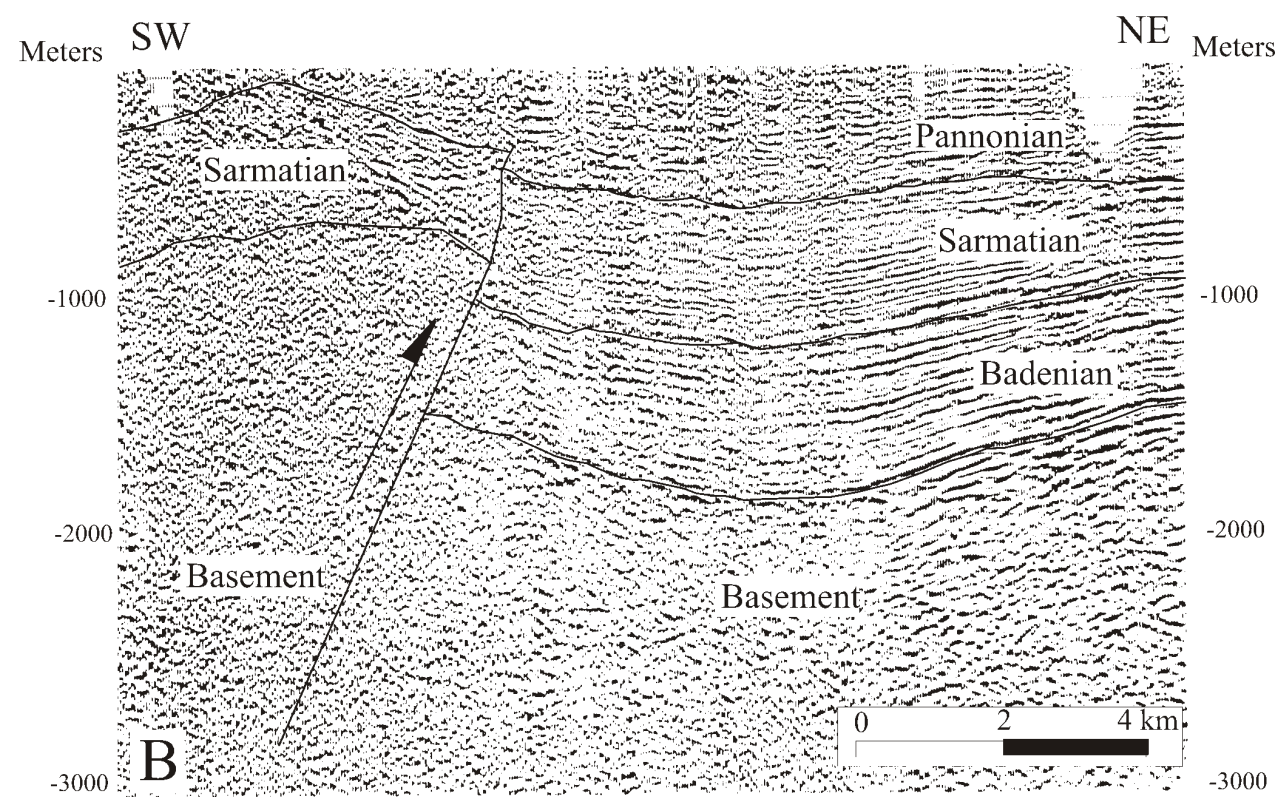

Fig. 6. (A) Seismic line 3, shot above the North Transylvanian Fault (see Fig. 3 for location). (B) Interpretation. The North Transylvanian Fault is interpreted in the southern part of the line as a high-angle, south-dipping fault with a reverse component. We speculate that is the northern splay of a positive flower structure. The offset is about of $200 \mathrm{~m}$. Only Sarmatian-Pannonian deposits and metamorphic basement were possible to be interpreted in the hanging wall. The Pannonian deposits are involved in thrusting.

\section{Transylvanian Basin}

Folds and salt diapirs represent the main late Miocene structures within the Transylvanian Basin (Fig. 8). The salt diapirism is related to the ongoing tectonics from the Carpathians and the salt diapirs location is controlled by the reactivation of inherited faults (Fig. 8) (Mrazec, 1907; Pauca, 1969; Visarion et al., 1976; Ciulavu and Berttoti, 1994;
De Broucker et al., 1998; and Ciulavu et al., 2000).

Latest Miocene and post-Miocene faults are also described in the Transylvanian Basin; most of them indicate strikeslip movement (e.g. De Broucker et al., 1998; Ciulavu et al., 2000). The Transylvanian Basin is crosscut by longlived crustal-scale vertical faults among which the westtrending South Transylvanian Fault represents the main fault in the southern part of the Transylvanian Basin (e.g. Ga- 


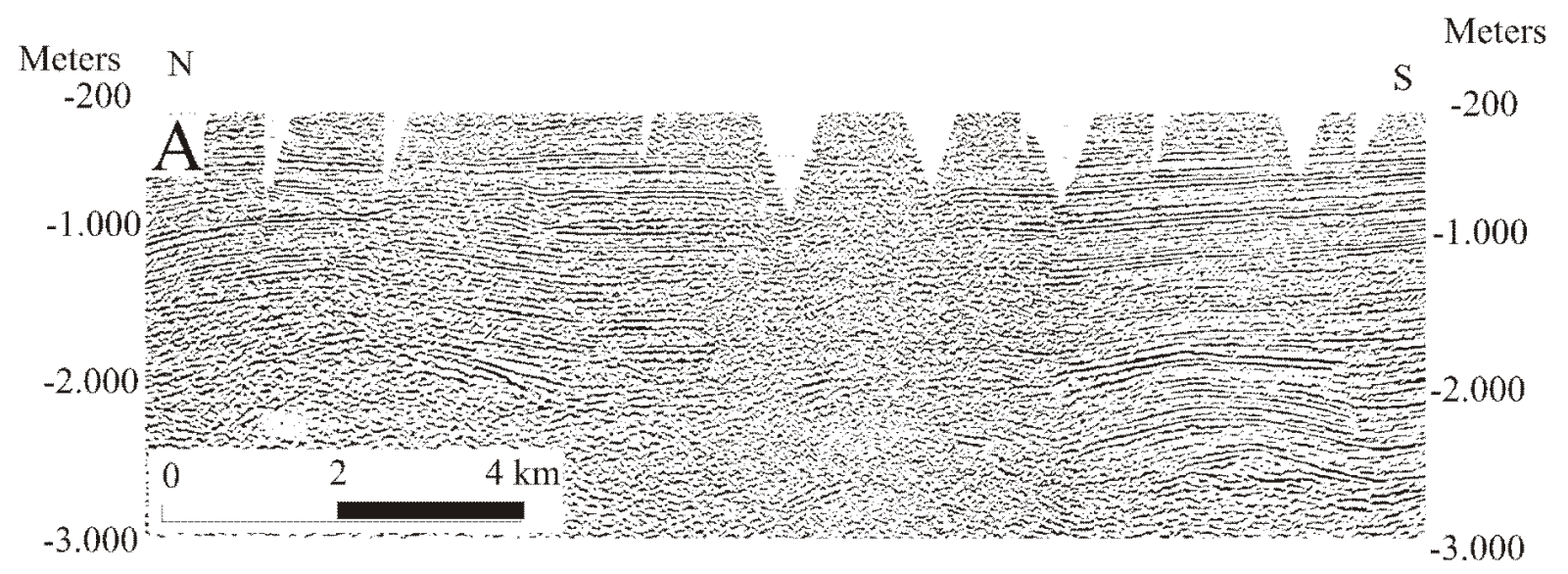

\section{Line 4}

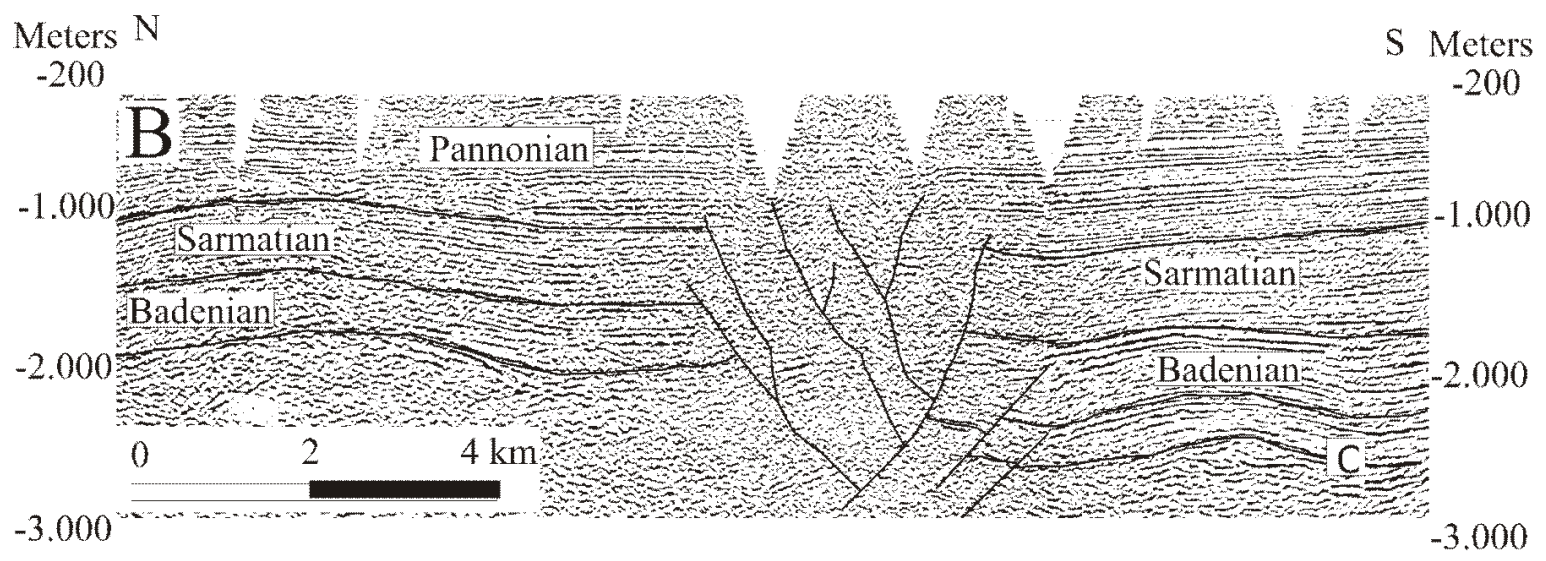

Fig. 7. (A) Seismic line 4, shot above a northwest-trending dextral strike-slip fault (see Fig. 3 for location). (B) Interpretation. Symbol C represents a pre-Badenian reflector. Upward diverging splays are interpreted in the central part of the line. These highly deformed areas preclude interpreting any sense of movement along this splays. Nevertheless, we speculate the structures mentioned above as being positive flower structures because of (1) the folding of the Badenian to Pannonian sedimentary deposits, and (2) the existence of two north-dipping thrust faults which offset the Badenian deposits.

vat et al., 1963) (Fig. 8). A sinistral movement is proved by field data along the South Transylvanian Fault during the late Cretaceous-Early Tertiary (Dumitrescu and Sandulescu, 1970). Since the Pliocene, the South Transylvanian Fault acted as a normal fault, with a downfaulting of its northern block (Sandulescu, 1988). A Pliocene sinistral movement has been also interpreted along it (Ciulavu et al., 2000). The best known late Miocene fault, namely
Cenade Fault, is evidenced in the southwestern part of the basin (Fig. 8). A southwestward movement was demonstrated along it (Ciulavu et al., 2000).

Two northwest-trending seismically active faults $(\mathrm{M}<3.3$ and focal depths up to $10 \mathrm{~km}$ ) are known in the northwestern part of the basin (Cornea and Lazarescu, 1980).

Several other faults have been assumed to play a major role in the late Miocene tectonic evolution of the Transylvanian 


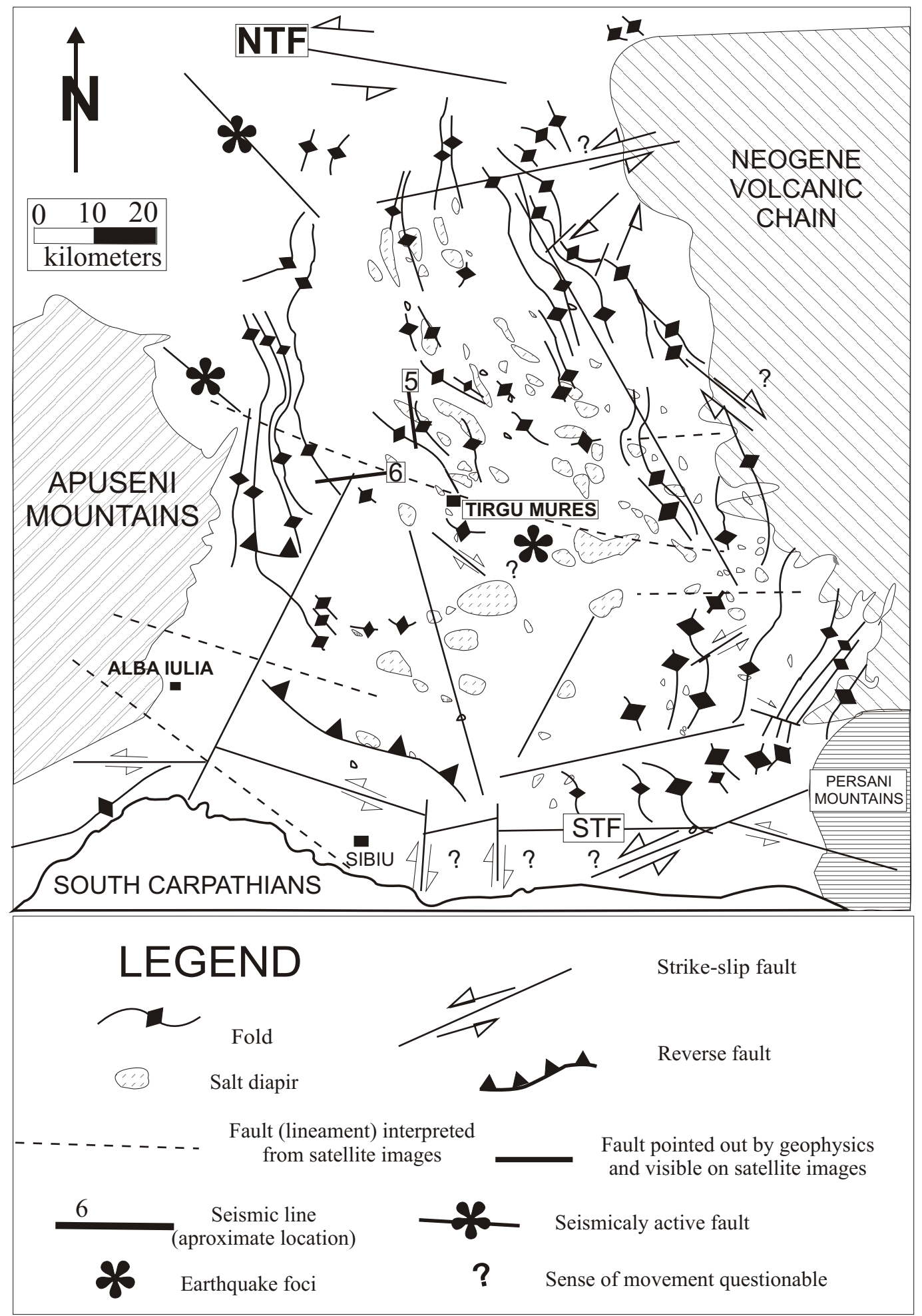

Fig. 8. Pattern of the folds, salt diapirs and main faults within the Transylvanian Basin, simplified after Ciulavu et al., 2000 (see Fig. 1 for location and text for description). The symbols represent NTF - North Transylvanian Fault and STF - South Transylvanian Fault.

Basin (Fig. 8). They are parallel to the previously described faults. Two west-trending lineaments in the eastern part of the basin have been detected on the satellite images (Ciulavu, 1999; Ciulavu et al., 2000).
The youngest uplift of the Transylvanian Basin borders is Pliocene (e.g. Berza, 1997). A present-day uplift of the basin borders is documented by geodetic measurements (Popescu and Dragoescu, 1986): (1) up to $2 \mathrm{~mm} / \mathrm{yr}$ of uplift in the 


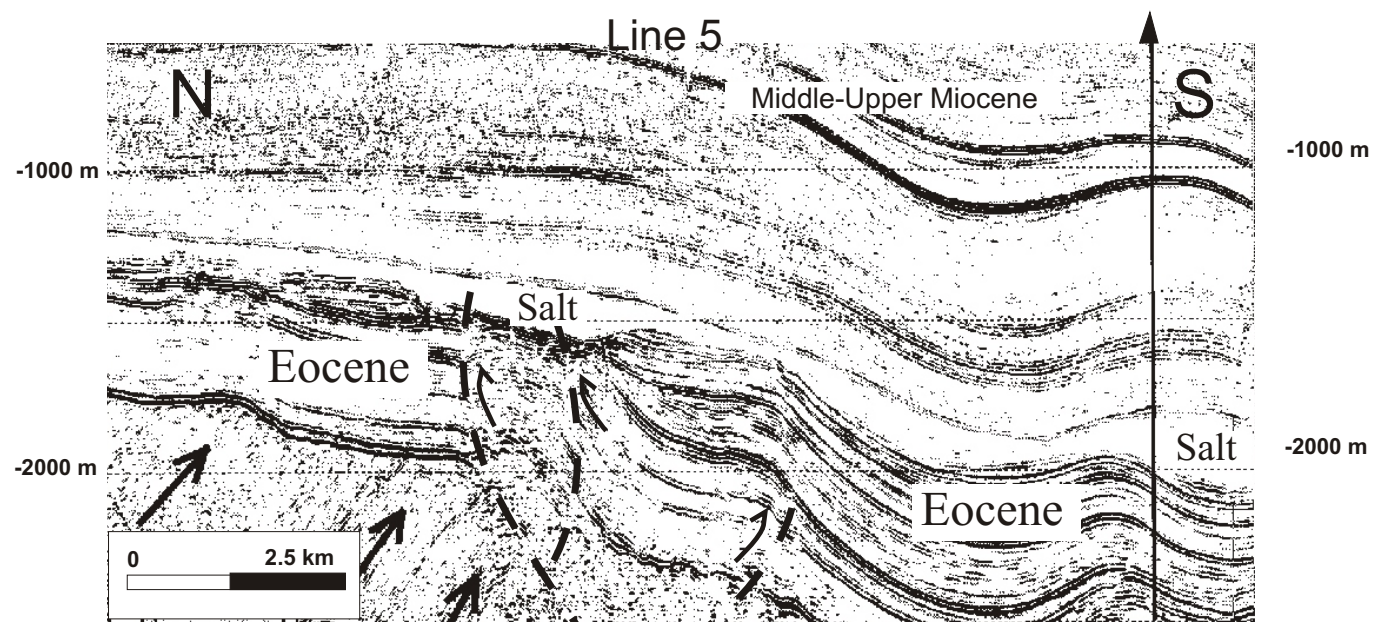

Fig. 9. Seismic line 5 (after De Broucker et al., 1998; Middle-Late Miocene structures are interpreted in this paper). Strike-slip faults in a transpressional regime have been interpreted at the boundary between the basement and the Eocene deposits. A reverse fault crosscutting the Eocene deposits has been interpreted east of the strike-slip faults. Middle-Upper Miocene drape folds are formed due to transpression.

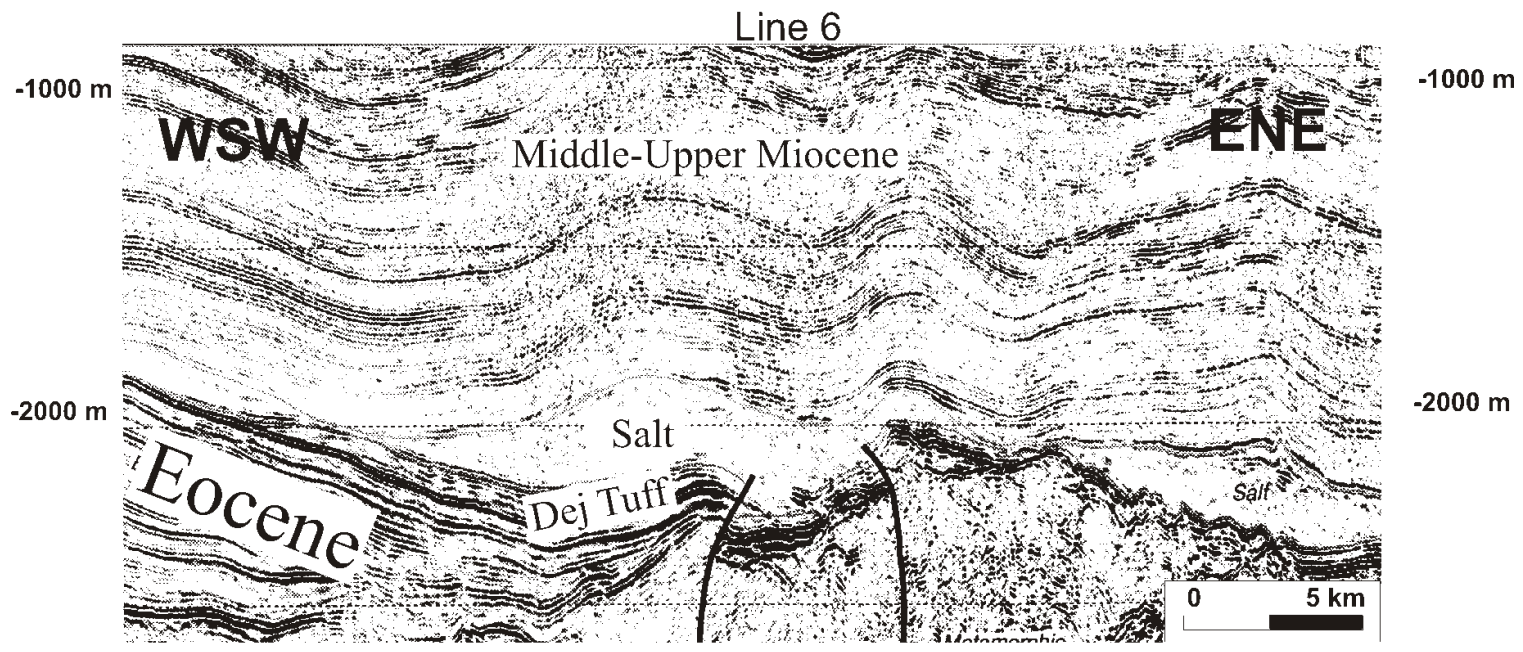

Fig. 10. Seismic line 6 (after De Broucker et al., 1998). Strike-slip faults formed in a transpressional regime.

Apuseni Mountains and in central part of the East Carpathians, and (2) up to $4 \mathrm{~mm} / \mathrm{yr}$ in the South Carpathians and in the northern sector of the East Carpathians. In contrast, subsiding areas are also documented by geodetic measurements: (1) up to $3 \mathrm{~mm} / \mathrm{yr}$ of the subsidence in the late MiocenePliocene basins from the inner part of the East Carpathians, (2) up to $1 \mathrm{~mm} / \mathrm{yr}$. in the northeastern part of the Pannonian Basin, and (3) up to $2 \mathrm{~mm} / \mathrm{yr}$ in front of the bend zone of the East Carpathians.

\section{Seismic lines from the Transylvanian Basin}

Most of the faults from the Transylvanian Basin are strikeslip faults formed in transpression. Transpressive strike-slip faults are located at the boundary between the basement and the Eocene sedimentary sequence in the central part of the
Transylvanian Basin (Fig. 9; see Fig. 8 for location). A thrust fault crosscutting the Early Eocene sedimentary sequence is located south of the strike-slip faults. The Middle-Upper Miocene sedimentary deposits are passively folded (drape folds) above these strike-slip and reverse faults. Therefore, a post-Miocene age is proposed for the faults.

Strike-slip faults formed in a transpressional tectonic regime have also been observed in the western part of the Transylvanian Basin (Fig. 10; see Fig. 8 for location). These strike-slip faults crosscut the Dej Tuff Formation (Lower Badenian) and control the salt diapirism and the folds within the Middle-Upper Miocene sedimentary deposits. Therefore, a post-Miocene age is assumed for these strike-slip faults. It should also be mentioned that these faults are located at an inherited discontinuity, i.e. at the boundary between the Eocene sedimentary sequence and the basement. 


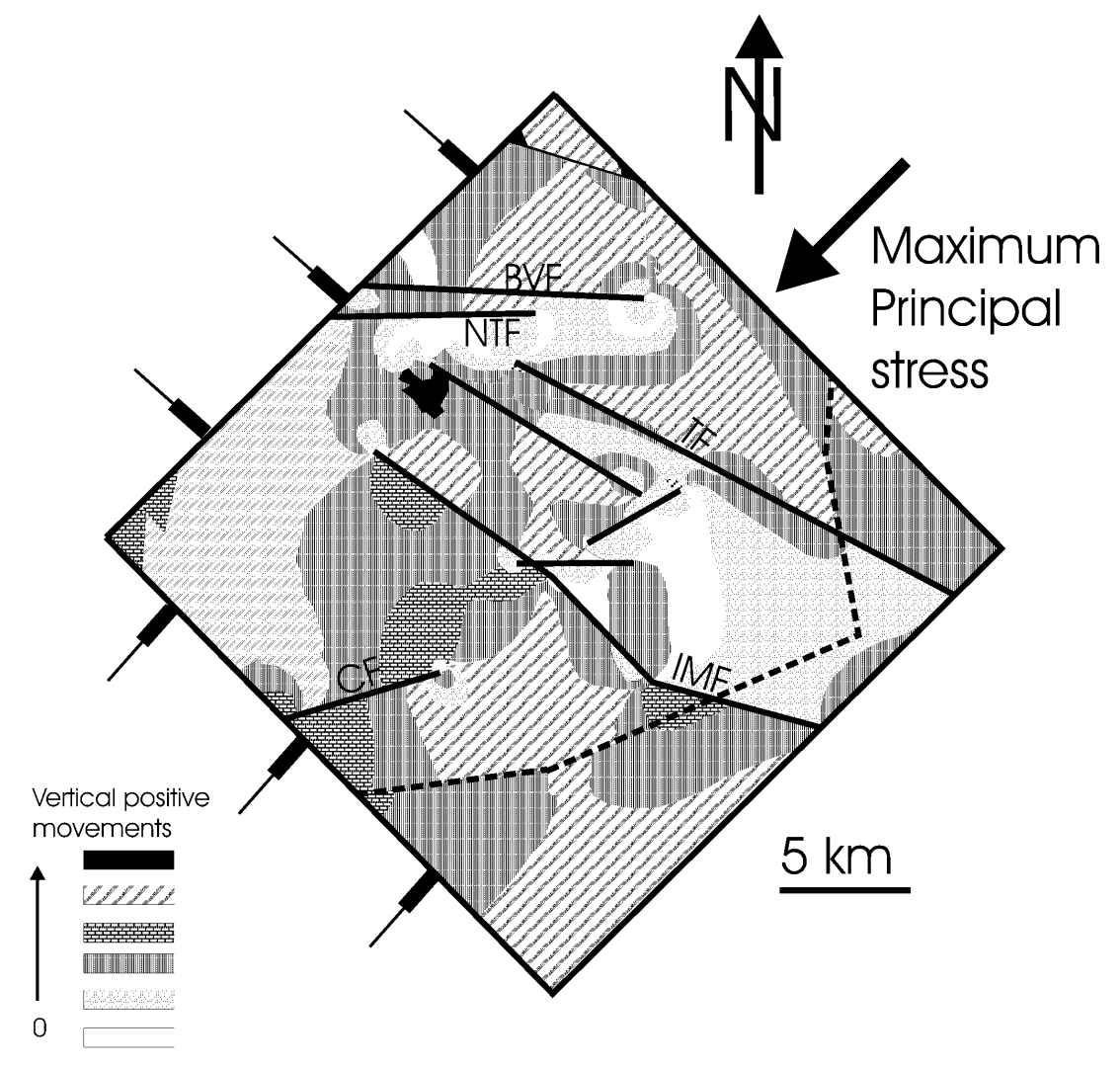

Fig. 11. Map of the vertical movements for the model with northwestern and southwestern fixed boundaries and compression from northeast. Symbols represent: BVF - Bogdan Voda Fault, NTF - North Transylvanian Fault, TF - Trotus Fault, IMF - Intra Moesian Fault, CF - Cerna Fault. The dotted line represents the boundary between the Carpathians and their foreland.

\section{Finite element model}

Transpressive strike-slip faults have been interpreted in seismic lines from both basins. Structural data from Transylvanian Basin and its rims indicate a late Miocene-Pliocene overall north- to northeast-oriented compression (Ciulavu et al., 2000). A finite element model has been carried out in order to test if the structures from the northeastern sector of the Pannonian Basin are also related to the stress field demonstrated in the Transylvanian Basin (Fig. 11).

Two scenarios with a northwest-oriented and northeastoriented far-field compressional stress, respectively have been used. A plane stress situation is considered. However, the out-of-plane strain can be interpreted as result of relative changes in topography, and therefore, it is the parameter of main interest of this model. Instantaneous strain patterns predicted by the finite element modeling, even instantaneously, are compared with the patterns (rather sequential), inferred from geological and geophysical data within these areas. The strain pattern is used instead of stress pattern because the second one, as inferred from borehole breakouts data, is still ambiguous in the modelled area (e.g. Negut et al., 1997).

The commercial finite element code ANSYS has been used for the model calculation. The model is designed as a square with $35 \times 35 \mathrm{~km}$ dimension with several predefined faults (Fig. 11). The boundaries of the model comprise the Carpathians foreland in the northeast and southeast, and the Pannonian Basin in the northwest and southwest, respectively.

The magnitude of loading has been kept constant and has been chosen $20 \mathrm{MPa}$ in order to account for the stress magnitude obtained in Western Europe, i.e. 20-30 MPa (e.g. Golke, 1996).

The finite element model developed contains two important simplifications:

(1) the model considers elastic rock properties despite more realistic depth-dependent rheological predictions available for the Romanian lithosphere (e.g. Cloetingh and Burov, 1996; Lankreijer et al., 1997; Lankreijer, 1997), and

(2) the model assumes a thickness of the plate equal to 1 mesh. The second simplification is reasonable since the model is designed to predict only the spatial patterns and relative amplitudes of deformations, but not their absolute values, and finite element modeling of recent tectonic stress in the Pannonian region indicates that additional stress such as crustal thickness variation have only locally important effects (Bada et al., 1998). 

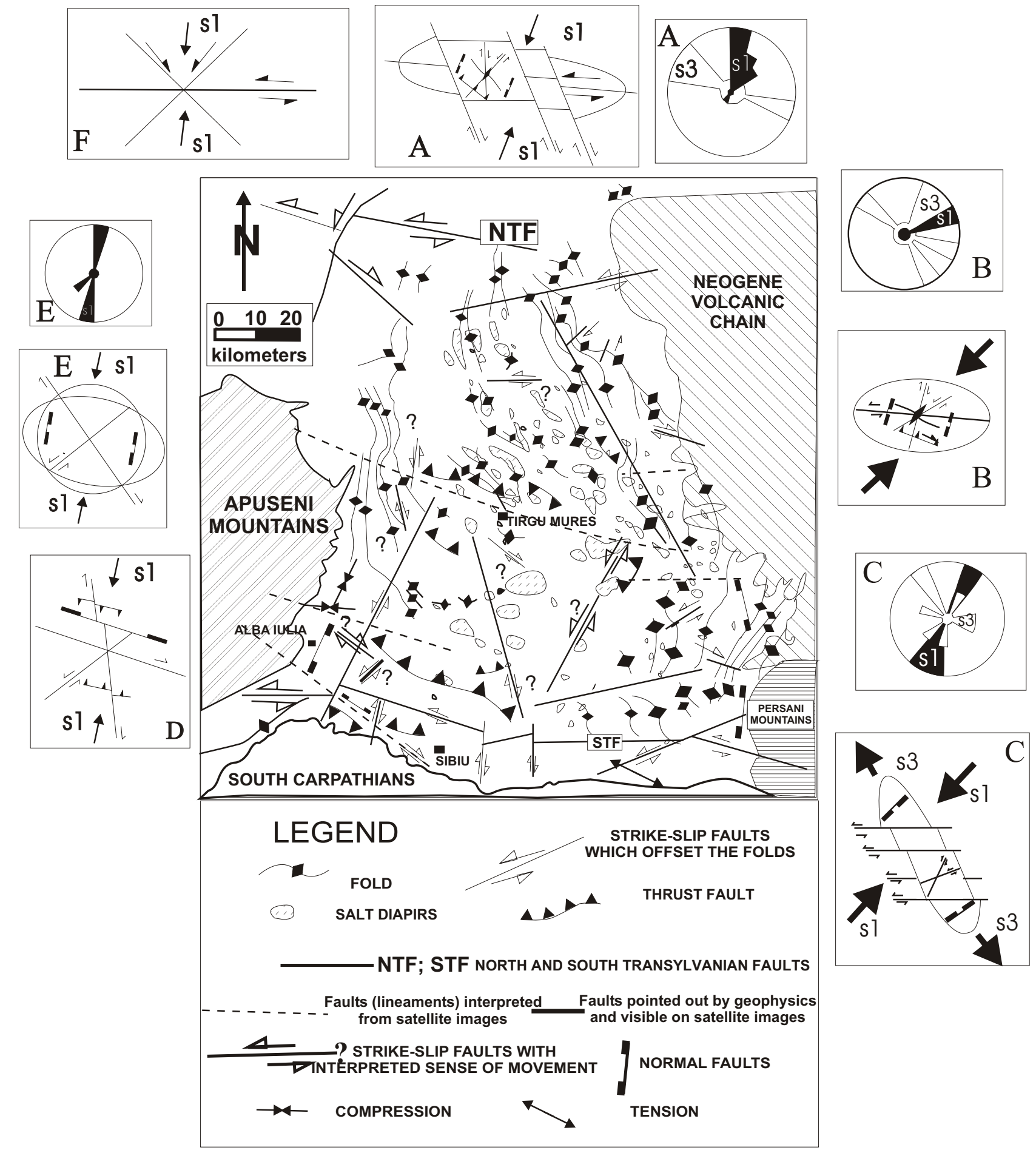

Fig. 12. Structural sketch of the studied areas updated after Ciulavu et al., 2000. For symbols see Fig. 8. The insets represent structural pattern and Rose diagram $\left(20^{\circ}\right.$ interval) of maximum $(\sigma 1)$ and minimum $(\sigma 3)$ principal stresses for: (A) - Maramures area, (B) - central and southern part of the Neogene volcanic chain, (C) - Birsa Depression, (D) - southwestern part of the Transylvanian Basin, (E) - Apuseni Mountains, and (F) - northeastern part of the Pannonian Basin.

Material properties have been chosen taking into account the rheological models of the area (Lankreijer et al., 1997; Lankreijer, 1997). Because a linear elastic rheology is used, reduction of Young's modulus by some factors will not affect the resulting displacement (e.g. ten Brink et al., 1996). The foreland of the Carpathians has been considered as being the stiffest (Young's modulus $=80 \mathrm{GPa}$ ). Intermediate material properties have been adopted for the block located between 
the Intra Moesian and Trotus faults and for the area north of the North Transylvanian Fault, because these areas show different structural patterns, i.e. different mechanical properties, compared to the other areas (Young's modulus $=70 \mathrm{GPa}$ ). Carpathians, Transylvanian and Pannonian basins as well as the Apuseni Mountains have been chosen the weakest blocks (Young' modulus $=60 \mathrm{GPa}$ ).

Fault zones have been chosen as the weakest domains (Young's modulus $=1 \mathrm{GPa}$ ), and as being 1 mesh wide. The strike-slip motion along faults which trend at very "unfavourable" orientation (aprox. $85^{\circ}$ to maximum principal stress) is documented in several oblique convergent plate boundary zones and take place because of a very low shear strength relative to surrounding crust (Zoback, 1994).

The Poisson's ratio has been chosen 0.25 for all materials. As obtained in different tests, the resultant deformation pattern is similar for Poisson ratio 0.25 or 0.5 , but the deformation magnitude is larger for the second case, i.e. 0.5 (Katzman et al., 1995).

Finite element modeling indicates that patterns obtained in the model which simulates a northeast-oriented far-field are similar to the patterns from the geological/geophysical data in the whole-modelled area. The main similarities are observed between the North Transylvanian and Bogdan Voda faults, south of the North Transylvanian Fault, and between the Trotus and Intra Moesian faults, respectively. In these regions, areas of extension (subsidence) alternate with areas of compression (uplift).

\section{Discussions and Conclusion}

Seismic lines have been used to highlight the late Cenozoic structure and evolution of the Transylvanian Basin and the northeastern part of the Pannonian Basin.

A Burdigalian thinning southward clastic wedge have been interpreted in the Transylvanian Basin. The Burdigalian deposits are missing in the northeastern part of the Pannonian Basin. The Badenian deposits have been interpreted in both studied areas. A middle Badenian uplift has been interpreted in the northern part of the Transylvanian Basin. In line 1, from the northeastern part of the Pannonian Basin, the Middle-Upper Badenian deposits are interpreted to be deposited in a piggy-back basin. The same structural pattern was also interpreted in the southern part of the Transylvanian Basin (T. Rabagia, pers. Comm., 1997).

Post Miocene transpressional strike-slip faults have been interpreted in both studied areas. The basement is involved in deformation. The strike-slip faults from the Transylvanian Basin are located at inherited discontinuities; this is not obvious for the northeastern sector of the Pannonian Basin.

Interpretation of the seismic lines from both studied areas indicates the same structural pattern starting from the late Miocene (Fig. 12). Therefore, the Transylvanian Basin and the Romanian northern part of the Pannonian Basin could be interpreted as the same block since the late Miocene.
The finite element modeling indicates that the complex late Cenozoic structural pattern observed within the studied areas, but also around them, is most likely the result of a coherent northeast-oriented far-field compressional stress.

Our structural data and finite element modeling results are in agreement to the results reported for the late MiocenePliocene time in the Romanian Carpathians and their foreland, as well as in the Transylvanian Basin (Bergerat, 1987; Ratschbacher et al., 1994; Hippolyte and Sandulescu, 1997; Matenco, 1997; Ciulavu et al., 2000).

The northeast-trending compressive stress field inferred in this paper is in contradiction with the west-east-trending stress field inferred in previous works (e.g. Bada et al., 1998). As pointed out by Negut et al. (1997) using borehole breakouts data, the stress pattern in this area is still ambiguous. Future structural work, seismic, borehole breakout data and focal plane solutions will better constrain the direction of maximum principal stress in this area.

At the regional scale, a Pliocene compressional inversion is documented in the Pannonian Basin (Horvath and Cloetingh, 1996). To conclude, the Pliocene intraplate stress field documented by Horvath and Cloetingh, (1996) acted and is probably active also in the Transylvanian Basin and the northeastern part of the Pannonian Basin.

Acknowledgements. The authors acknowledge Romanian National Agency for Mineral Resources for permission to use the seismic lines. Dr. Francois Roure and an anonymous reviewer are thanked for their constructive comments which improved this paper.

\section{References}

Bada, G., Cloetingh, S. A. P. L., Gerner, P., and Horvath, F.: Sources of recent tectonic stress in the Pannonian region: inferences from finite element modeling, Geophys. J. Int., 134, 87-101, 1998.

Bergerat, F.: Stress fields in the European Platform at the time of Africa-Eurasia collision, Tectonics, 6, 2, 99-132, 1987.

Berza, T.: A hundred years of tectonic studies in South Carpathians: the state of the art, in: Grubic, A. and Berza, T. (Eds.): Geology of Djerdap area, Yougoslavia and Romania, Belgrade Geoinstitute special edition, 25, 271-277, 1997.

Bleahu, M.: Structure géologique des monts Apuseni septentrionaux, Rev. Roum. géol., géophys., géogr., Géol., 20, 1, 27-39, 1976.

Bleahu, M., Marinescu, F., Stancu, J., and Ghenea, C.: Geological map, Scale 1:200 000, Satu Mare, I.G.R., Bucharest, Romania, 1967.

Borcos, M.: Volcanicity/metallogeny in the South Amuseni Mts. (Metaliferi Mts.), in: Borcos, M. and Vlad, S. (Eds.): Plate tectonics and metallogeny in the East Carpathians and Apuseni Mountains, IGCP Project, 356, 32-44, 1994.

Brink ten, U. S., Katzman, R., and Lin, J.: Three-dimensional models of deformation near strike-slip faults, Jour. Geoph. Res., 101, B7, 16 205-16220, 1996.

Ciulavu, D.: Tertiary tectonics of the Transylvanian Basin, $\mathrm{PhD}$ Thesis, Vrije Universiteit, Amsterdam, 152 pp, 1999.

Ciulavu, D., Dinu, C., Szakacs, A., and Dordea, D.: Neogene kinematics of the Transylvanian Basin (Romania), AAPG Bulletin, 84, 10, 1589-1615, 2000. 
Ciulavu, D. and Berttoti, G.: The Transylvanian Basin and its Upper Cretaceous substratum: ALCAPA II Field Guidebook, Romanian Journal of Tectonics and Regional Geology, 75, supp. 2, 59-65, 1994.

Ciupagea, D., Pauca, M., and Ichim, Tr.: Geology of the Transylvanian Depression, Edit. Acad. R.S.R., Bucharest, 255 pp., (in Romanian), 1970.

Cloetingh, S.,A.P. L. and Burov, E. B.: Thermomechanical structure of European continental lithosphere: constraints from rheological profiles and EET estimates, Geophys. J. Int., 124, 695723, 1996.

Cornea, I. and Lazarescu, V.: Tectonics and geodynamic evolution of Romania, State Committee for Nuclear Energy, Institute of Physics, Research Center of Earth Physics and Seismology, (in Romanian), 89 pp., 1980.

De Broucker, G., Mellin, A., and Duindam, P.: Tectonostratigraphic evolution of the Transylvanian Basin, Pre-Salt sequence, Romania, in: Dinu, C. (Ed.): BGF Special volume 1, 36-70, 1998.

Demetrescu, I. and Veliciu, S.: Heat flow and lithospheric structure in Romania, in: Cermak, V. and Rybach, L. (Eds.): Terrestrial heat flow and lithospheric structure, Springer-Verlag, Berlin, 187-205, 1991.

Dumitrescu, I. and Sandulescu, M.: Tectonic map of Romania, Scale 1:1 000 000, Geological atlas of Romania, sheet 6, I.G.G., Bucharest, 1970.

Gavat, I., Airinei, St., Botezatu, R., Socolescu, M., Stoenescu, Sc., and Vencov, I.: Romanian deep-structure inferred from gravimetric and magnetic data, Stud. Cerc. Geol. Geof. Geogr., Geofizica, 1, 1 (in Romanian), 7-34 1963.

Gölke, M.: Patterns of stress in sedimentary basins and the dynamics of pull-apart basin formation, $\mathrm{PhD}$ Thesis, Vrije Universiteit Amsterdam, 167 pp, 1996.

Harding, T. P.: Identification of wrench faults using subsurface structural data: criteria and pitfalls, AAPG Bulletin, 74, 15901609,1990

Hyppolite, J. C. and Sandulescu, M.: Paleostress characterization of the "Wallachian" phase in its type area, Southeastern Carpathians, Romania, Tectonophysics, 263, 235-249, 1997.

Horvath, F.: Towards a mechanical model for the formation of the Pannonian basin, Tectonophysics, 226, 333-357, 1993.

Horvath, F. and Cloetingh, S. A. P. L.: Stress induced late-stage subsidence anomalies in the Pannonian Basin, in: Cloetingh, S. ,A. P. L., Ben Avraham, Z., Sassi, W., and Horvath, F. (Eds.): Dynamics of extensional basins and inversion tectonics, Tectonophysics, 266, 287-300, 1996.

Huismans, R. S., Bertotti, G., Ciulavu, D., Sanders, C., Cloetingh, S. A. P. L., and Dinu, C.: Structural evolution of the Transylvanian Basin (Romania): a sedimentary basin in the bend zone of the East Carpathians, Tectonophysics, 272, 249-268, 1997.

Katzman, R., ten Brink, U. S., and Lin, J.: Three-dimensional modeling of pull-apart basins: implications for the tectonics of the Dead Sea Basin, Jour. Geoph. Res., 100, 6295-6312, 1995.

Lang, B., Edelstein, O., Steinits, G., Kovacs, M., and Halga, S.: ArAr dating of adularia - a tool in understanding genetic relations between volcanism and mineralization: Baia Mare (Gutii Mountains), northwestern Romania, Economic Geology, 89, 174-180, 1994.

Lankreijer, A., Mocanu, V., and Cloetingh, S. A. P. L.: Lateral variations in lithosphere strength in the Romanian Carpathians: constraints on basin evolution, Tectonophysics, 272, 269-290, 1997.

Lankreijer, A.: Rheology and basement control on extensional basin evolution in Central and Eastern Europe: Variscan and AlpineCarpathian-Pannonian tectonics, PhD Thesis, Vrije Universiteit Amsterdam, 157 pp, 1997.

Matenco, L.: Tectonic evolution of the Outer Romanian Carpathians: constraints from kinematic analysis and flexural modeling, $\mathrm{PhD}$, Thesis, Vrije Universiteit Amsterdam, 160 pp, 1997.

Mrazec, L.: About the salt diapirs, Bul. Soc. St., 16, Bucharest, (in Romanian), 1907.

Negut, A., Dinu, C., Savu, I., Bardan, R., Negut, M. I., and Craicu, I.: Stress orientation determination in Romania by borehole breakouts: Geodynamic significance, Rev. Roum. Geol., 34, 23 35, 1997.

Nicorici, E. and Meszaros, N.: Delimitation et subdivisions du Miocene en Europe et leur application sur certaines regions de Roumanie, in: The Miocene from the Transylvanian Basin, Romania, Babes-Bolyai University, Cluj, Romania, 5-19, 1994.

Pauca, M.: Problèmes tectoniques dans le Bassin de Transylvanie, Geologische Rundschau, 58, 520-537, 1969.

Pecskay, Z., Lexa, J., Szakacs, A., Balogh, K., Seghedi, I., Konecny, V., Kovacs, M., Marton, E., Kaliciak, M., Szeky-Fux, V., Poka, T., Gyarmati, P., Edelstein, O., Rosu, E., and Zec, B.: Space and time distribution of Neogene-Quaternary volcanism in the Carpatho-Pannonian region, Acta Vulcanologica, 7 (2), 15-28, 1995.

Popescu, M. and Dragoescu, M.: The new map of recent crustal movements in Romania, Scale 1:1000000, Rev. Roum. géol., géophys., géogr., Geophys., 30, 3-10, 1988.

Ratschbacher, L., Linzer, H. G., Moser, F., Strusievicz, R. O., Bedelean, H., Har, N., and Mogos, P. A.: Cretaceous to Miocene thrusting and wrenching along the central South Carpathians due to a corner effect during collision and orocline formation, Tectonics, 12, 855-873, 1993.

Rögl, F.: Stratigraphic correlation of the Paratethys Oligocene and Miocene, Mitteilungen der Gesellschaft der Geologie und Bergbaustudenten in Österreich, 41, 65-75, 1996.

Roman, C.: Seismicity in Romania-evidence for the sinking lithosphere, Nature, 288, 1176-1178, 1970.

Rosu, E., Percskay, Z., Stefan, A., Popescu, Gh., Panaiotu, C., and Panaiotu, C.: The evolution of the Neogene volcanism in the Apuseni Mountains (Romania): constraints from new K-Ar data, Geologica Carpathica, 48, 6, 353-359, 1997.

Roure, F., Roca, E., and Sassi, W.: The Neogene evolution of the outer Carpathian flysch units (Poland, Ukraine and Romania): kinematics of a foreland/fold-and-thrust belt system, Sedimentary Geology, 86, 177-201, 1993.

Royden, L.: Evolution of retreating subduction boundaries formed during continental collision, Tectonics, 12, 629-638, 1993.

Sanders, C.A.E.: Tectonics and erosion, competitive forces in a compressive orogen. A fission-track study to the Romanian Carpathians, PhD Thesis, Vrije Universiteit Amsterdam, 204 pp, 1998.

Sandulescu, M.: Cenozoic tectonic history of the Carpathians, in: Royden, L. and Horvath, F. (Eds.): The Pannonian Basin: A study in basin evolution, Mem. AAPG, 45, 17-25, 1988.

Sandulescu, M.: Geotectonics of Romania, Edit, Acad. R.S.R., Bucharest (in Romanian), 334 pp., 1984.

Sandulescu, M., Visarion, M., Stanica, D., Stanica, M., and Atanasiu, L.: Deep structure of the inner Carpathians in the Maramures-Tisa zone (East Carpathians), Rom. Jour. Geophysics, 16, 67-76, 1993.

Tari, G.: Alpine tectonics of the Pannonian Basin, PhD Thesis, Rice University Houston, Texas, 501 pp, 1994. 
Visarion, M., Polonic, P., and Ali-Mehmed, E.: New data on the geometry of salt diapirs from Transylvanian Basin, Stud. Tehn. Econ., D, Geof., 11, (in Romanian), 29-62, 1976.

Visarion, M., Polonic, P., and Ali-Mehmed, E.: New geophysical data from the northeastern area of the Pannonian Basin and surrounding areas, Stud. Tehn. Econ., D, 12, (in Romanian), 45-57,
1979.

Zoback, M. L.: Present day stress in plate boundaries zones: influence of relative motions and plate geometry, Peri-Tethyan Platforms, in: Roure, F. (Ed.): Editions Technip, Paris, 121-128, 1994. 